\title{
Poesia do luto através da imagem: uma visita aos campos da memória
}

DOI: https://doi.org/10.35168/2176-896X.UTP.Tuiuti.2020.Vol6.N61.pp122-147 


\section{Poesia do luto através da imagem: uma visita aos campos da memória}

\section{Resumo}

O presente artigo apresenta uma reflexão teórico-prática sobre a fotografia autoral no contexto da memória afetiva paterna, partindo do pensamento em torno da ressignificação do luto pós-morte, através de processos artísticos que envolvem objetos relacionados a essa figura familiar. A pesquisa teórica sobre a memória afetiva partirá especialmente da autora Carolina Junqueira dos Santos, numa pesquisa de sua tese de doutorado e a questão da memória fotográfica contará com Georges Didi-Hubberman, Roland Barthes e Glenda Cuman. Sobre a metodologia de progressos e os procedimentos no fazer artístico, influências como Sandra Rey, Rosana Paulino e Cecília Almeida Salles. O processo de criação do trabalho ocorreu inicialmente através de insights, escritos, desenhos em esboços. Foi realizado no contexto do espaço familiar, com o uso de iluminação natural e posterior manipulação digital para tratamento de cor, recorte e montagem da série em unidade, dípticos, trípticos e quadrípticos. Deste modo, a intenção dessa figuração imagética pretende atentar para uma relação objeto - corpo - memória e as relações que estas unidades ou conjuntos de fotografias fazem com a ideia de ausência versus sobrevivência dos traços, pauta principal do artigo.

Palavras-chave: Fotografia. Luto. Memória Afetiva. Figura Paterna. Objetos Afetivos. 


\section{Poesia do luto através da imagem: uma visita aos campos da memória}

\section{Apresentação}

O artigo se origina a partir de um processo pessoal de luto pós-morte do meu pai e da memória afetiva vinculada a ele; trato aqui sobre a fruição de alguns objetos que lhe pertenceram, outros que, de alguma forma, remetem ao espaço físico onde ele viveu - especialmente em seu último estágio de vida - e alguns que me foram presenteados por ele. A partir disso, lanço algumas reflexões como ponto de partida para a realização do ensaio fotográfico e desta produção textual, tais como: quais as possíveis relações que se estendem a partir do objeto - autor, com o campo da memória e a ausência do corpo físico paterno; quais os elementos simbólicos que esses objetos de afeição carregam no processo de luto, na preservação da memória e quais as formas de se expressar esse afeto, bem como a presença-ausência, com tais objetos por meio da arte.

Como um reflexo de subjetividade relacionada à morte e as memórias, o trabalho compartilha pontos-de-vista e vivências pessoais, sugere pensamentos e questões acerca da morte, do luto e da memória além do retrato fotográfico, também realizados por meio de outras influências artísticas, bem como escritos autorais, esboços poéticos e experimentações fotográficas diversas. Utiliza o ato da fotografia como resultado de processo artístico, para fins de registros dos objetos em questão, bem como deles em contato comigo. Para isso, "[...] a pesquisa desenvolve-se em duas direções opostas e complementares: o pensamento estruturado da consciência e um afrouxamento das estruturas inconscientes“ (REY, 2002, p. 124).

Com relação à estrutura do artigo, temos o primeiro tópico em que será abordada a questão da memória afetiva embasada no pensamento de Carolina Junqueira dos Santos; posteriormente, no segundo tópico, os apontamentos sobre a memória fotográfica contarão com Didi-Hubberman, Carolina Junqueira dos Santos, Roland Barthes e Glenda Cuman. Nas influências teóricas sobre a metodologia e processo artístico, os pensamentos de Sandra Rey, Rosana Paulino e Cecília Almeida 


\section{Poesia do luto através da imagem: uma visita aos campos da memória}

Salles, sobre o ofício do fazer através de diversas influências, como por exemplo, as anotações e desenhos à mão que fiz dentro do processo, como parte da construção desse trabalho. Na inspiração dos procedimentos práticos, a influência da artista visual brasileira Thaís Itapema, que trabalha com regressões em álbuns familiares (termo que utiliza no sentido de rememorar passagens, voltar no tempo através da fotografia e trabalhar artisticamente a partir dessa questão), realizando intervenções fotográficas nos mesmos, assemblage com diversos elementos, trazendo uma linguagem poética aos seus trabalhos, reforçando a questão da memória e a artista francesa Sophie Calle, que fez um trabalho em homenagem à sua mãe utilizando desde fotografias a outros objetos relacionados à ambas, trabalhos estes relacionados diretamente com a memória e as formas de representação da mesma.

\section{MEMÓRIA AFETIVA: o cântico dos rastros}

Nesse tópico será abordada a questão da memória afetiva a partir do pensamento da Carolina Junqueira dos Santos, no seu artigo "Um lugar para o corpo: fotografias familiares em contexto de luto" na qual a autora menciona o termo "presentificação" - "[...] eleito aqui para se pensar a especificidade da representação do corpo do morto depois que o corpo original (o corpo de carne) desaparece da vista“" (SANTOS, 2017, p. 16).

Partindo desse pensamento, busco observar essa relação da memória, em conjunção com o objeto familiar-afetivo e a fotografia também como registro da obra final, considerando nessa captura - aprofundada através de um processo que me acompanha e que foi sendo desenvolvido - a sobrevivência de um traço sobre esse objeto, presentificando essa figura paterna através da ressignificação deles. Sua presença, sua passagem por ali, e de certa forma, o sentimento ali impregnado. 


\section{Poesia do luto através da imagem: uma visita aos campos da memória}

Refiro-me ao objeto como afetivo-familiar, pois, inicialmente eles pertenceram a essa figura paterna e em determinado espaço de tempo, eles também remeteram ao meu pai uma memória que era sua, histórias de sua própria vida. Houve então um zelo, uma preservação e um afeto desenvolvido por esses elementos. Deste modo, eles estão carregados de subjetividade, portanto, são ternos não de maneira gratuita, nem pela estética ou sua função prática, eles têm por si sua face, seu aspecto de força intrínseca.

Meu pai vem de uma criação de vida simples, relacionada a hábitos campestres, rodeado de criação de animais, do fazer artesanal e arranjado. O crânio ${ }^{1}$ de boi, presente que ganhei dele, é um dos objetos que mais me transmite essa força - uma observação sobre a resistência da natureza ao tempo - no qual, para cada forma de vida, existe um fim diferente e como é possível a permanência de algo, mesmo quando nesse algo já não se respira vida. As flores secas, usadas junto ao crânio de boi na fotografia que ilustra o artigo, eram de aspecto e cores vivas, faziam juntas um colar que os familiares receberam numa cerimônia de um ano de sua morte. O pingente de bailarina, também presente dele quando eu ainda era criança, me leva à essa infância, quando eu fazia ballet na escola e todas as coisas que esse tempo perpetuou em mim. Os acessórios lapidados em formato de cabeça de boi, como uma referência aos gostos da cultura gaúcha, serviam para usar com a camisa preta e o lenço vermelho nas idas aos bailes de C.T.G. (Centro de Tradições Gaúchas), bastante corriqueiros em determinada época de sua vida. Um barulho de facão sendo afiado me faz novamente voltar à infância - como num dia domingo, na preparação do almoço, meu pai afiava o facão para o corte de alguma carne que seria preparada em breve - nesse facão perpetuam as marcas dessa audição, a sua ação está no cabo que substitui o original e também na lâmina, com as marcas de uso. Quando

1 Nota da autora: Dada continuidade à pesquisa, nesse adendo mais especificamente sobre o mencionado crânio animal que pertenceu ao meu pai, foi constatado que, apesar da semelhança aproximada ao crânio bovino sem chifres, trata-se de um crânio equino, considerando a relevância observada da parte occiptital e parietal do mesmo que diferem ambos em suas formas.

Revista Tuiuti: Ciência e Cultura, v.6 n.61, p. 122-147, Curitiba, 2020 


\section{Poesia do luto através da imagem: uma visita aos campos da memória}

éramos criança, se caíssemos e batêssemos a cabeça no chão, meu pai colocava uma lâmina de faca sobre o "galo" para que desinchasse, fiz assim uma alusão, utilizando o canivete que foi dele para fazer essa ligação com o passado. As lamparinas eram acesas quando faltava luz em nossa casa do sítio, elas ainda guardam o cheiro de querosene da última vez em que foram acesas. Algumas pedras do rio que corria ao lado da casa, sendo uma delas - sobre a qual acendi velas e fiz rezas, especialmente logo após sua morte - considerada a "nossa pedra". A árvore que foi plantada por ele em frente à nossa casa resiste ao tempo, bem como a mesa feita com toco de árvore, que ele mesmo criou e montou, e que era muito utilizada na casa do sítio. As carcaças foram abertas como janelas para que pássaros ocupassem e tornassem casas temporárias para si e seus filhotes. Além desses objetos mencionados, existem outros não inseridos diretamente nesse trabalho, como vinis, cuias, roupas, objetos que eram de minha avó e ficaram com ele, posteriormente comigo, acessórios, dentre outros.

A memória em si, consiste em sentir essa encarnação de subjetividade deixada nos objetos, desses vestígios paternos que ali ainda emergem; assim, é iniciada uma retomada de ecos do passado, o ato de recordar. Essas memórias junto à relação que se faz com o objeto constituem uma espécie de corpo, um corpo especial, um corpo que não existe verdadeiramente num sentido físico (humano), mas que agora só existe no sentido onírico (imaginativo). É como tornar algo vivo, ainda que se tratando inicialmente de um corpo humano ausente. É a memória familiar-afetiva viva, "[...] - o tornar presente, esse sentido dado pela presentificação, só é possível no afeto: o amor como agente do estado mágico dos objetos que nos ligam ao morto, que lhe reconstrói um corpo" (SANTOS, 2017, p. 19).

Os objetos então escolhidos para fazer parte desse baú de memórias são como chaves na mencionada retomada dos ecos, eles remontam momentos de vida; são memórias visuais, sensoriais, de infância e vida adulta, que, a sua forma, fazem trânsitos dentro da existência 


\title{
Poesia do luto através da imagem: uma visita aos campos da memória
}

relacionada a essa figura paterna, renovando sentimentos que remetem a ele, como um certo preenchimento que desperta alegria, força, simplicidade. Como uma herança, esses objetos formam uma espécie de memorial.

Portanto, esse trabalho usa a fotografia como veículo para registro do resultado de um processo em que há uma forma de expressão da ausência paterna, representando essa ausência por meio do objeto e autorretrato. O resultado das reflexões se materializa a partir do ensaio fotográfico, objetivado no próximo tópico.

\subsection{MEMÓRIA FOTOGRÁFICA: refazendo trajetos}

\begin{abstract}
Ensine sua dor a falar em voz alta e aprenda com ela a pisar as pedras. Como pisar as fotos. Pisar os trevos. Como pisar as distâncias. Pisar os dias. As memórias. Como atravessar o solo seco até o encontro das chuvas. Da nossa casa. Sem lamentos. Na substância dos dias, a terra é egrégora. Assim nos correspondemos com a Ausência. [Thaís Itapema]
\end{abstract}

Nesse tópico será abordado a questão da memória fotográfica, embasando-me no pensamento de Didi-Hubberman no texto "O rosto e a terra - Onde começa o retrato, onde se ausenta o rosto"; Carolina Junqueira dos Santos no texto "Um lugar para o corpo: fotografias familiares em contexto de luto"; o livro "Câmara Clara", de Roland Barthes e o artigo "[Des]Ausências: preenchendo lacunas", de Glenda Cuman. Também, recorro às escritas do meu processo de luto postados numa rede social e que se relacionam pelo tom poético com o livro "Diário de Luto" de Barthes e o vídeo "A morte é um dia que vale a pena viver" da médica Ana Claudia Quintana Arantes.

Como um diário de sentimentos em torno do luto, uma forma de expressão desses sentimentos no decorrer desse trajeto e com um fluxo de pensamentos não ensaiado, escrever o meu dia-a-dia 


\section{Poesia do luto através da imagem: uma visita aos campos da memória}

no convívio dessa ausência paterna me trazia certo alívio, como se eu estivesse falando a um alguém o meu processo, colocando nesses espaços públicos (redes sociais) minhas questões internas, o que me rondava, o que me feria - fotografia, objeto, lembrança, morte - como um local de troca e desabafo, um diário aberto. Nesse sentido, inclusive, Cuman comenta que "[...] de alguma forma a perda não é uma questão somente minha, já que o luto é um fenômeno natural“ (CUMAN, 2017, p. 11). Mas que, conforme dito por Arantes no vídeo "A morte é um dia que vale a pena viver": "O sofrimento é único. Cada um tem o seu” (ARANTES, 2013).

FIGURA 1 - CRUZ, Mônica Lachman da. Sem título, 2017.

Mônica Lachman
11 de julho de 2017
Hoje já faz um mês que não ouço mais a sua voz, pai. Sua risada.
Como eu queria poder reviver alguns instantes, como seu abraço.
Desejo de coração que o Sr. esteja em um lugar de muita paz, como
realmente merece e almejava.
Sinto muita saudade. Às vezes sinto dor.
Sei que nossos sentimentos mais difíceis vão se acalentar aos poucos, a
gente só precisa ter calma.
Paizão! C
(0) Lucidez Budne, Day Luiza e outras 59 pessoas
$\square$ Curtir

Fonte: $<$ https://www.facebook.com/lachman.monica $>$.

Considerando assim ser uma fase subjetiva, onde cada um elabora de maneira diferente sua forma de ressignificar o acontecimento. Em meus métodos de desenvolvimento artístico teórico e prático utilizei da escrita e das artes como parte da elaboração do pensamento sobre o que é o luto 


\section{Poesia do luto através da imagem: uma visita aos campos da memória}

e a transformação que pode ocorrer quando envolvido pela arte e pela fotografia, trazendo uma nova face de compreensão sobre o processo de aceitação da morte.

Percebo que olhar para algum retrato familiar onde meu pai está presente é intenso e íntimo, instantaneamente ocorre algo como um efeito de congelamento do tempo presente - é como se olhasse para ele aqui e agora, presente em sua forma física nesse intervalo de tempo - intervalo esse em que a memória pode transitar por aquele acontecimento específico da foto ou época, e, “[...] se a aura ainda acena nos retratos familiares, isso diz respeito a seu valor afetivo, associado a um valor de culto. Mas também diz respeito ao seu valor de real, do "ter acontecido" (SANTOS, 2017, p. 13) - mas quando se volta ao estado natural do presente é cabível a realidade de que "[...] as fotografias são objetos melancólicos, que fingem restituir algo, prometendo um corpo, uma volta, mas que logo escapam, deixando-nos sós" (SANTOS, 2017, p. 25), pois aquela ausência existe, ela só é, momentaneamente preenchida por lembranças.

Didi-Hubberman comenta em seu texto a questão do retrato pós-morte, referindo-se aos mesmos como rostos esvaziados, definindo-os com a função de poetizar, preencher, representar simbolicamente. Tratando o retrato como "[...] a ausência sagrada do rosto". Nesse sentido, o autor enfatiza que "[...] o que os retratos fariam, depois de tudo, seria apenas poetizar - isto é, produzir - uma tensão sem recurso entre a representação dos rostos e a difícil gestão de sua perda“ (DIDIHUBERMAN, 1998, p. 62).

Com base nesse pensamento, constato que a fotografia é uma escolha para a prática do lembrar, um caminho para a preservação da memória sobre os acontecimentos. Ela também servirá, nesse trabalho, como conservação desta, tanto do objeto afetivo, quanto das relações e reflexões que foram desenvolvidas e resgatadas a partir e através dele, presentificando essa ausência paterna através da poética visual das relações objeto - corpo - memória desenvolvidos em um ensaio fotográfico que será apresentado no seguinte tópico. 


\title{
Poesia do luto através da imagem: uma visita aos campos da memória
}

\section{PROCESSO FOTOGRÁFICO: um caminhar sobre as memórias}

\author{
Seus olhos devem estar abertos para sua própria vida interior, seus ouvidos sempre atentos \\ à voz da necessidade interior. (...) Todos os procedimentos são sagrados. [Kandinsky]
}

Trazendo para o presente artigo uma influência na prática do pensar acerca do fazer artístico, do processo de construção do trabalho e do seu resultado: a obra, Rosana Paulino comenta que "[...] o/a artista deve sempre trabalhar com aquelas questões que the são mais profundas [...]" (PAUlinO, 2011, p. 25).

Tratando da motivação que faz então o artista produzir algo: dentre tantas, refiro-me especificamente ao processo artístico que tive dentro do contexto de luto e sua relação com a matéria (objeto) e memória.

Adotei um caminho com o qual me identifico e que, de certa forma, se faz presente nos meus dias atuais. Observar a questão poética do trabalho, buscar a relação da arte com a vida e do que faz sentido para mim, me redescobrir nos processos e ressignificar as questões que o trabalho propõe, me fizeram compreender o meu processo artístico e perceber alguns movimentos nesse campo que trata do luto e da memória afetiva como elementos poéticos da minha produção. $\mathrm{O}$ desenvolvimento desse trabalho é, então, o compartilhamento de questões internas, espaço que utilizo para expressar reflexões e sentimentos. Conforme dito por Paulino, "[...] aquele que cria, deve sempre estar atento para as coisas que lhe tocam profundamente, procurando nunca fugir ao desafio de lidar com esses assuntos" (PAULINO, 2011, p. 20).

A fotografia é como uma transposição da vida, um arquivo de memória visual, um laço afetivo que atravessará o tempo. Reconectar-me às memórias em torno do meu pai, é como reavivar 


\section{Poesia do luto através da imagem: uma visita aos campos da memória}

sentimentos que poderiam adormecer com o passar do tempo, é alimentar com o silêncio, com a saudade, com a tristeza, alegria, enfim "[...] o afeto provoca a magia da imagem: ele faz retornar qualquer coisa de perdido” (SANTOS, 2017, p. 19).

A ideia de realizar um trabalho relacionado à figura paterna, se deu inicialmente na participação em uma oficina de arte, após uma experiência sinestésica com alguns elementos, sendo um deles o qual remeteu às suas lembranças. Através do cheiro do levedo, visualizei um fragmento de memória do meu pai - de costas - e logo, imaginei uma música, lembrei de uma passagem da infância, de quando meus pais faziam cerveja caseira. Foi uma sensação que reverberou em outras lembranças. Com isso, construí um breve material que ilustrava essa experiência. Esse, então, foi o marco inicial, o impulso para outras diversas faces que a pesquisa em torno da memória haveria de florescer.

FIGURA 2 - CRUZ, Mônica Lachman da. Sinestesia, 2018. Tríptico, colorida.
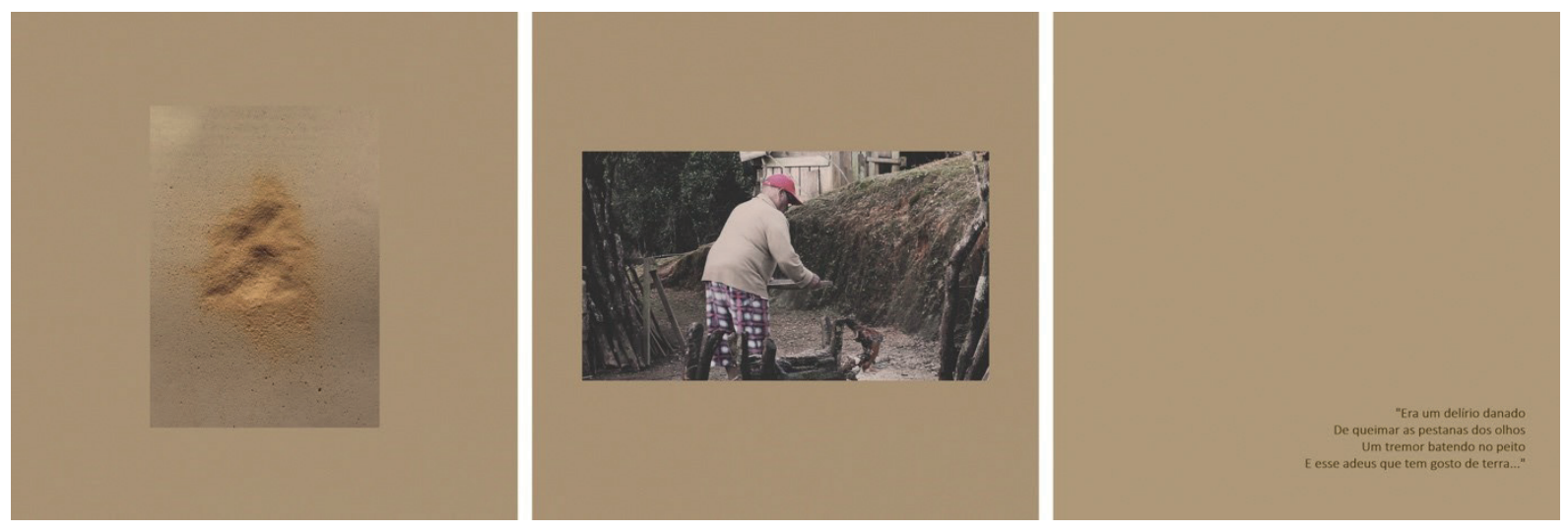

Fonte: Acervo Pessoal. 


\section{Poesia do luto através da imagem: uma visita aos campos da memória}

O processo de construção e criação desse trabalho teórico e prático que discorro tem sua fonte no sentimento de afeto e passou a se desenvolver e evoluir a partir de pensamentos/ ideias, anotações, esboços de desenhos para experimentações práticas na fotografia, fragmentos de reflexões poéticas, insights, resultante de diversas possibilidades: estado físico de relaxamento/ meditativo, aulas de arte, músicas, pré-sono e leituras relacionadas ao assunto, servindo como caminhos para o projeto fotográfico-poético e o fazer artístico.

Lembrando o que Rey cita em seu texto sobre as três dimensões na instauração de uma obra:

[...] uma primeira dimensão, abstrata, processa-se no nível do pensamento e revela-se na forma de ideias, de esboços, muitas vezes sem grandes intenções, em algumas anotações improvisadas ou em projetos mais elaborados, que poderão, ou não, se concretizar em obras. Num segundo plano, temos a dimensão da prática feita de procedimentos, manipulações técnicas ou operacionais, reações de materiais ou substâncias, assim como o estabelecimento de interfaces com os mais avançados processos tecnológicos. E, num terceiro nível - como tudo o que se cria não surge do nada, mas é uma resposta mais ou menos qualificada a um certo estímulo -, a obra em processo conecta-se com tudo o que diz respeito ao conhecimento (REY, 2002, p. 124, grifos do autor).

Rey comenta também sobre a criação de estratégias, como por exemplo, a ideia de “[...] manter um diário de anotações (secreto) durante o processo de elaboração do trabalho prático, no qual possamos escrever todos os nossos pensamentos, sem censura [...]" (REY, 2002, p. 130-131), trecho este que se relaciona tanto com as anotações feitas por mim em esboços, bem como as que se referem ao "diário aberto", quando me referi ao compartilhamento do processo de luto na rede social, que também faz a relação com o livro "Diário de Luto" de Barthes, mencionado no desenvolvimento deste artigo. 


\section{Poesia do luto através da imagem: uma visita aos campos da memória}

FIGURA 3 - CRUZ, Mônica Lachman da. Sem Título, 2019. Escritos, colorido.

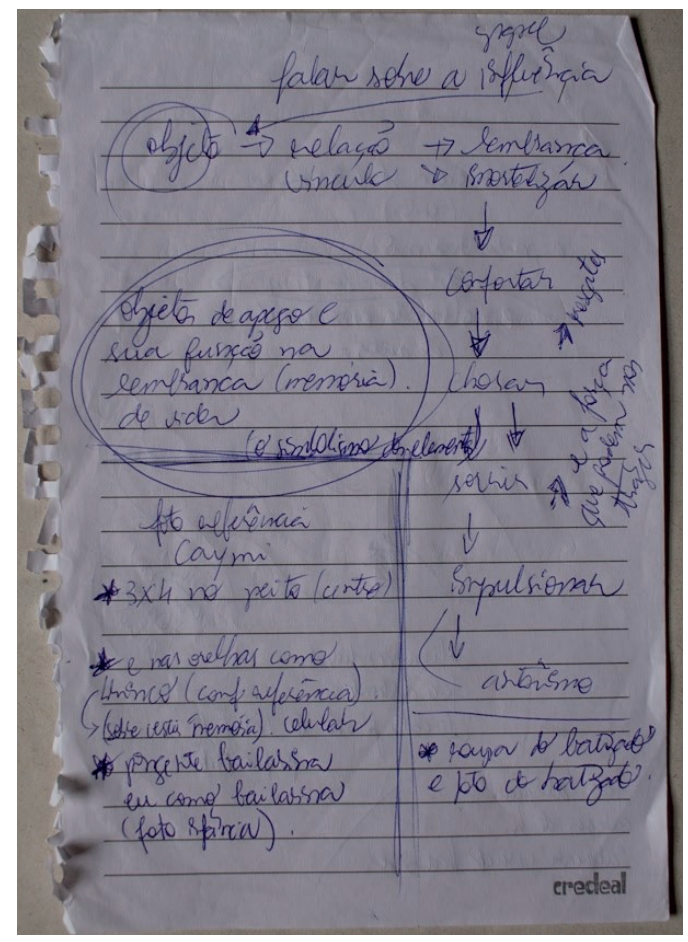

Fonte: Acervo pessoal.

Às vezes, a ideia inicial de transformar o texto ou desenho em obra era alcançada com êxito, mas também ocorreram imprevistos, nomeados por Salles como "ação do acaso" (SALLES, 2003, p. 96), mostrando, em muitas das vezes "o poder criativo do acaso" (SALLES, 2003, p. 97), sendo assim o processo marcado pelo estado da construção e transformação constantes. 


\section{Poesia do luto através da imagem: uma visita aos campos da memória}

FIGURA 4 - CRUZ, Mônica Lachman da. Sem Título, 2019. Desenho, colorido.

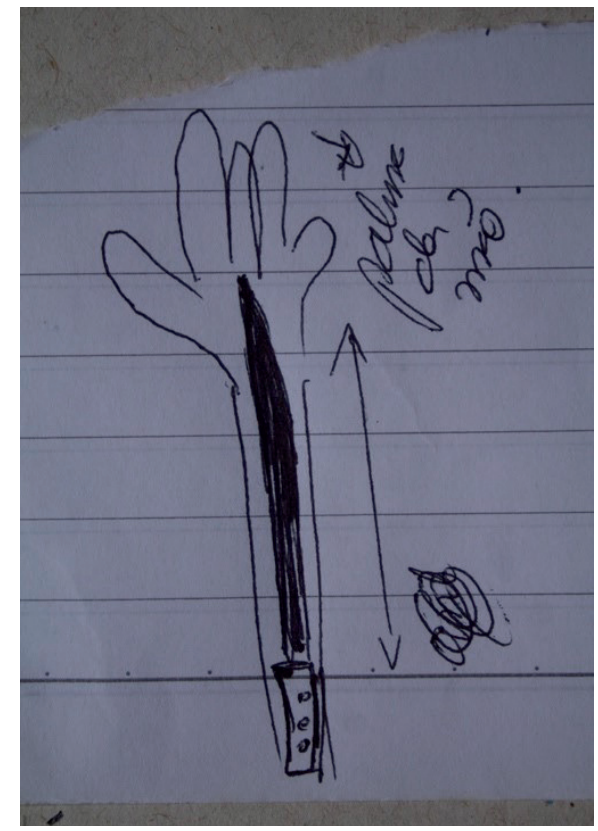

Fonte: Acervo pessoal.

Diversas fotografias que resultaram de algo num primeiro momento, posteriormente foram descartadas, ou, de alguma forma, reutilizadas, passaram por evoluções e/ou interferências, serviram de inspiração e também como objetos de composição para realização de novas fotografias, portanto, fizeram transições dentro do trabalho por terem passado por uma transformação dentro da leitura teórico-visual que ele foi tomando. 


\section{Poesia do luto através da imagem: uma visita aos campos da memória}

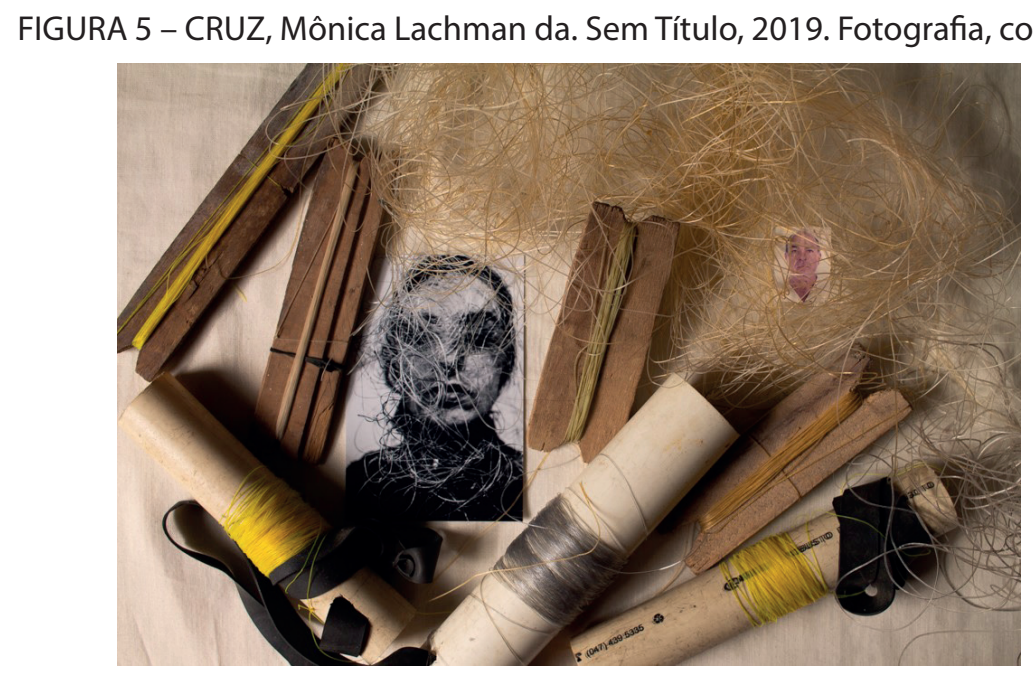

Fonte: Acervo pessoal.

Salles menciona em seu texto uma anotação do artista visual brasileiro Daniel Senise que, de certa forma, faz referência ao que foi citado acima:

A tela das panelas é um trabalho único - pontual. E a presença dela no projeto da exposição está atrapalhando o 'processo"'. Algumas semanas depois a tela é reavaliada: "A tela das panelas da qual tanto me orgulhei há pouco mais de um mês, agora já não me causa encanto. Sinto que é um pequeno apêndice no meu trabalho [...] Não permite divagações. É o que propõe (SALLES, 2003, p. 100).

Tenho esse trabalho como autoral e intuitivo, motivados pelos impulsos que tenho ao fazê-lo, tão relacionados ao processo da escrita - esboço - tentativa - obra. Para criar foi preciso me conectar à questão do luto e me livrar por alguns instantes das amarras relacionadas a outros assuntos- é 


\section{Poesia do luto através da imagem: uma visita aos campos da memória}

nesse instante que possivelmente vem o sopro no apoio de criação, para que o sentimento seja então posto para fora.

Menciono aqui duas artistas que me serviram de inspiração para o resultado desse trabalho artístico: Thais Itapema, artista brasileira, que direciona seu trabalho a regressões em álbuns familiares, trabalhando intervenções através de assemblage, envolvendo seus trabalhos em ares poéticos, ressignificando assim, a forma de observar a ausência física de um ente - influenciando e inspirando em mim ideias de construção e montagem estética da obra final que compõe a memória do meu pai, através de elementos naturais já existentes, tornando-a, além de fotografia, uma força simbólica.

FIGURA 6 - ITAPEMA, Thaís. "Comunhão". Regressões em álbum de família, 2018. Assemblage com tórax de sabiá laranjeira, sementes de lágrima de nossa senhora, polinizadores (abelha operária e zangão; joaninha), colmeia, gotas de seiva, pigmento de urucum. Fotografia, colorida.

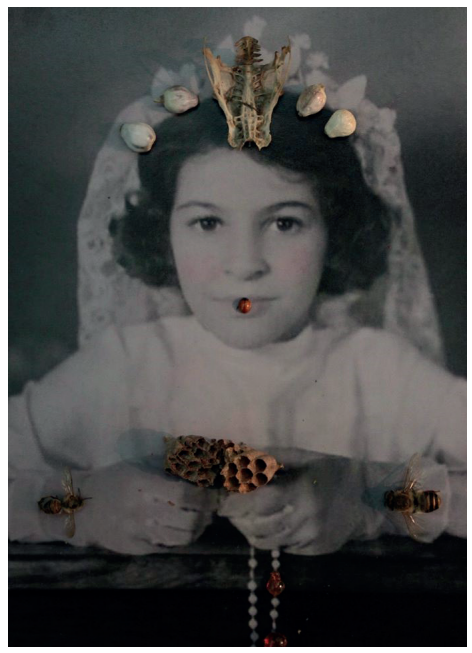

Fonte: <www.facebook.com/mascataria.onirica $>$. 


\section{Poesia do luto através da imagem: uma visita aos campos da memória}

Já a artista francesa Sophie Calle, que realizou um trabalho em homenagem a mãe, utilizando em seu resultado uma instalação com objetos que faziam ligação a essa figura materna, transformando nesse espaço uma espécie de memorial, um oratório, me inspirando, portanto, na intenção de preservar uma memória através de um objeto, imantando nele uma importância, algo de sagrado.

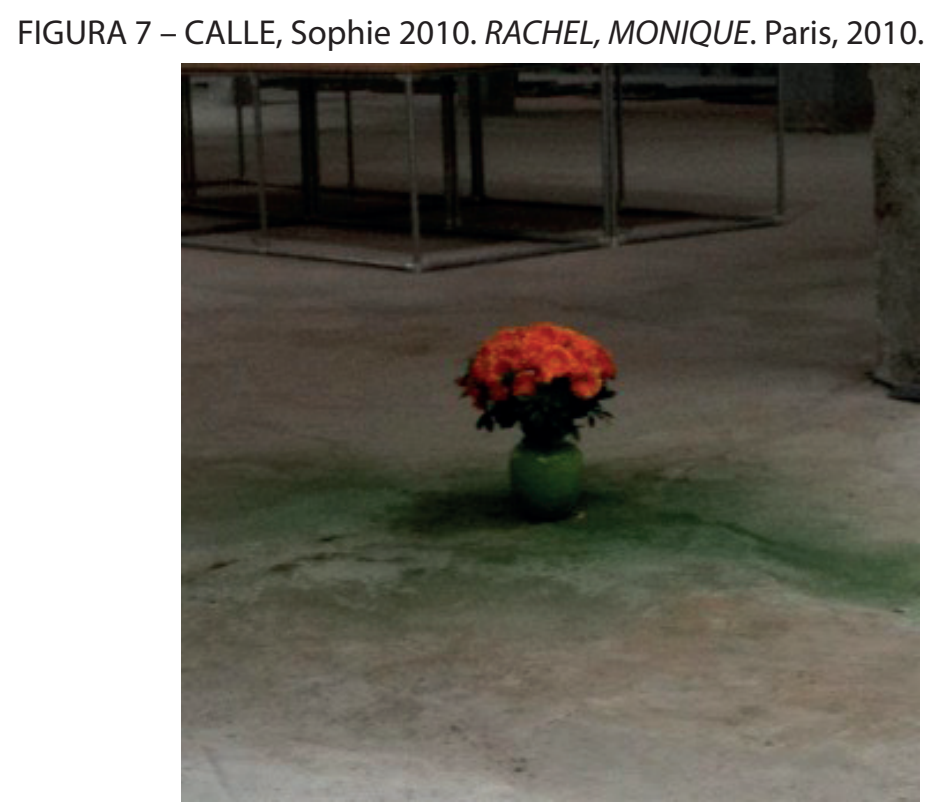

Fonte: <http://www.martinesonnet.fr $>$.

A seguir, o resultado parcial do processo artístico desenvolvido, resultante das pesquisas realizadas no decorrer desse estudo da arte e fotografia. 


\section{Poesia do luto através da imagem: uma visita aos campos da memória}

FIGURA 8 - CRUZ, Mônica Lachman da. Sem Título, 2019. Díptico, colorida.
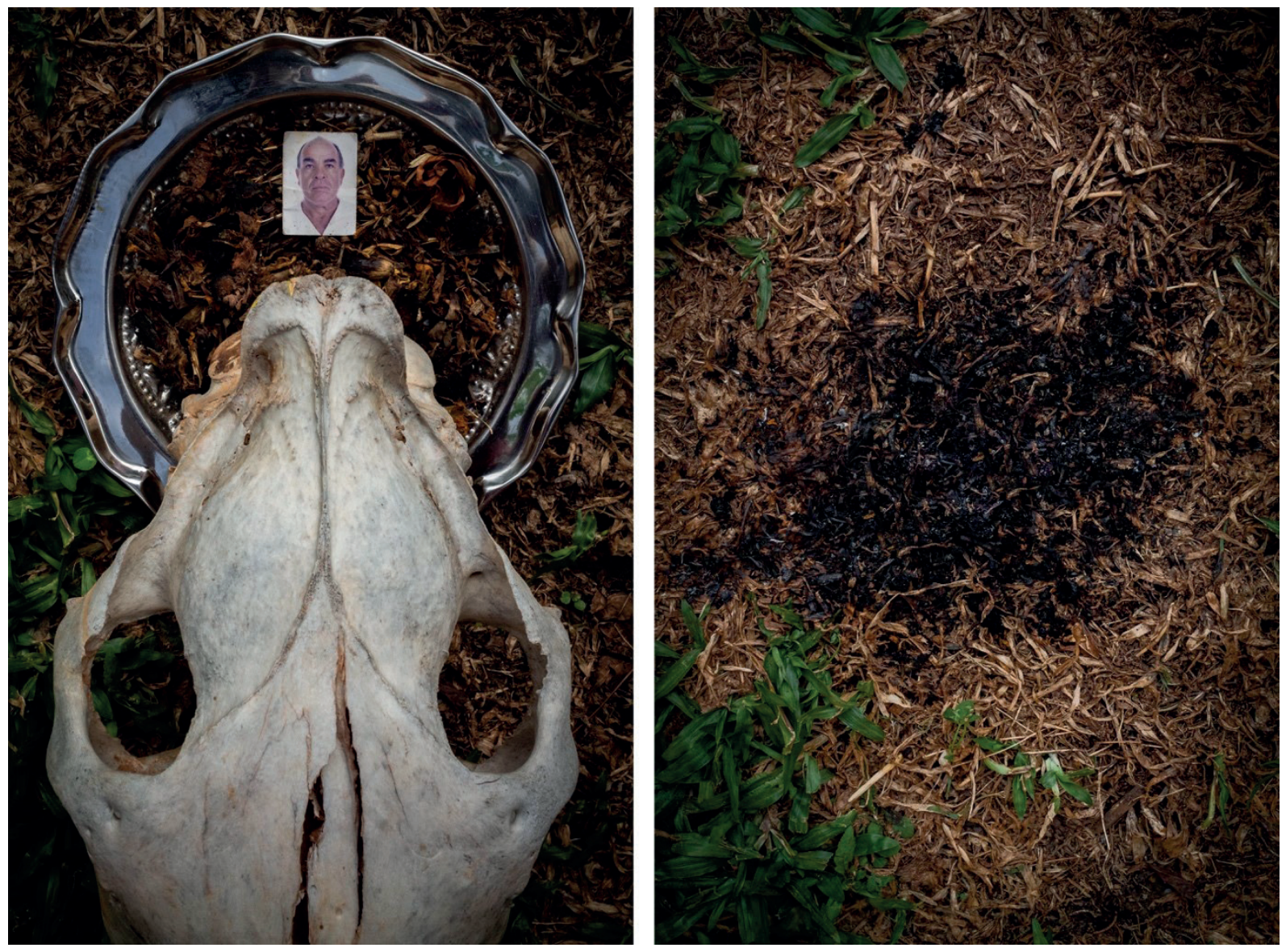

Fonte: Acervo pessoal. 


\section{Poesia do luto através da imagem: uma visita aos campos da memória}

FIGURA 9 - CRUZ, Mônica Lachman da. Pé de Palhaço, Pé de Bailarina, 2019. Díptico, colorida.
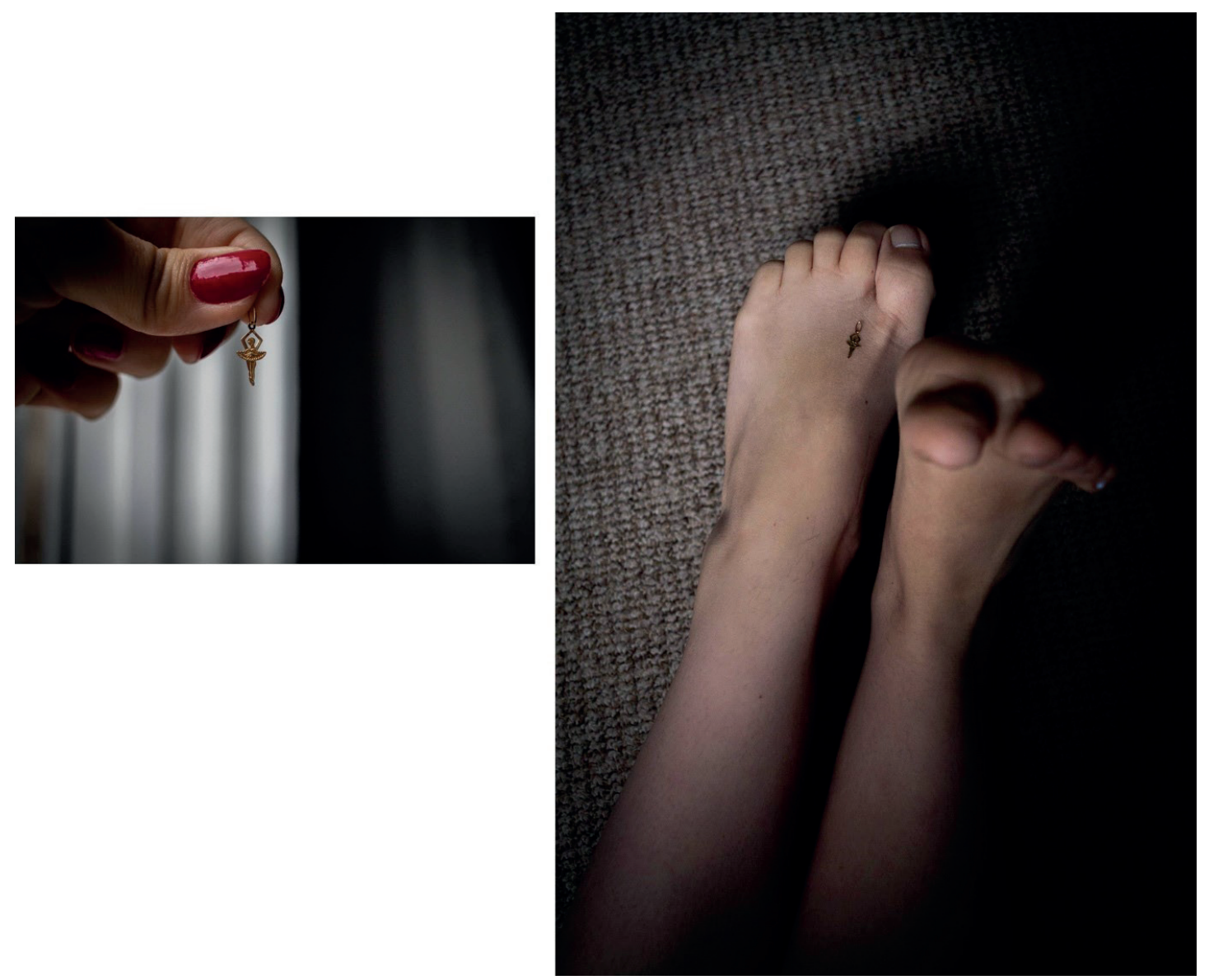

Fonte: Acervo pessoal. 


\section{Poesia do luto através da imagem: uma visita aos campos da memória}

FIGURA 10 - CRUZ, Mônica Lachman da. Sem Título, 2019. Quadríptico, colorida.
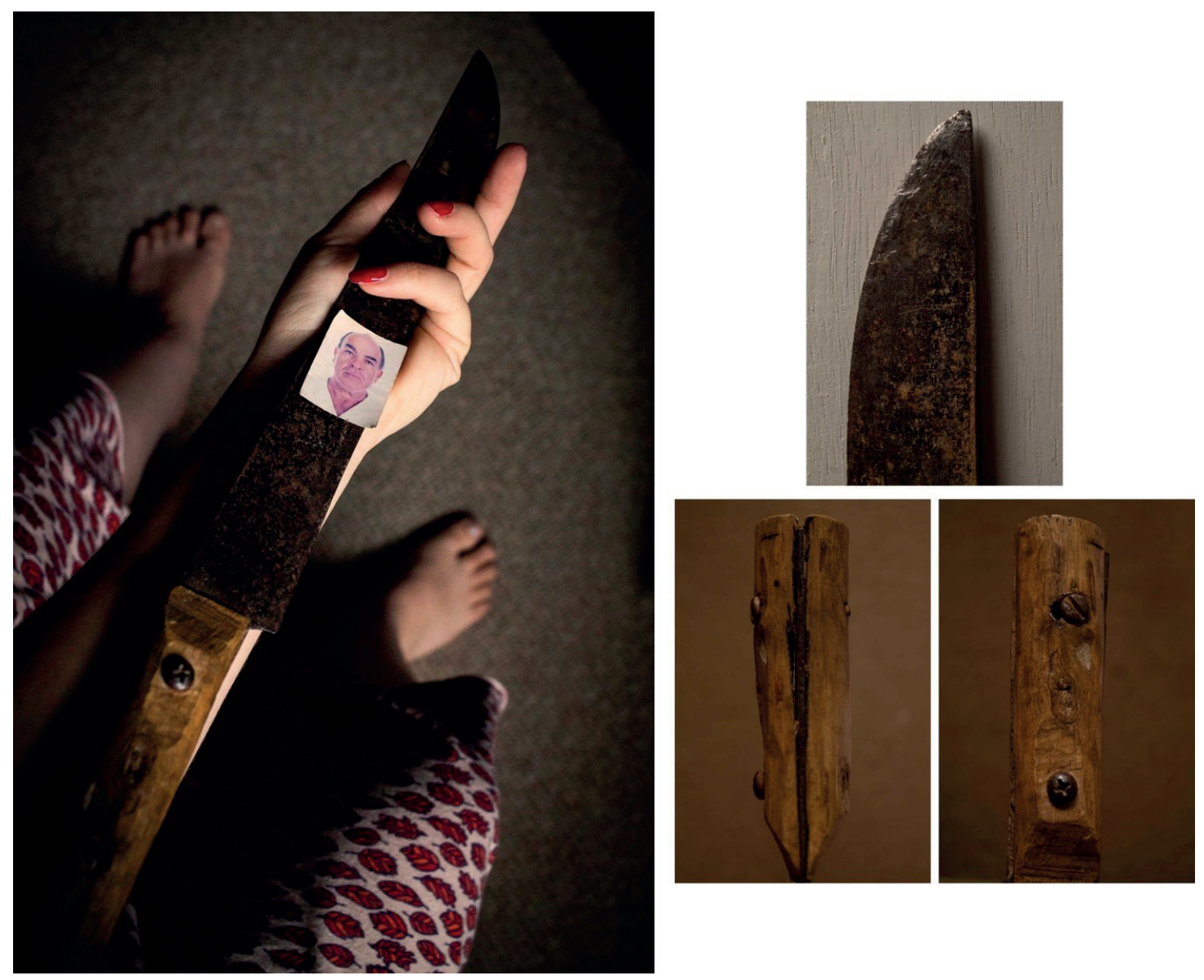

Fonte: Acervo pessoal. 


\section{Poesia do luto através da imagem: uma visita aos campos da memória}

FIGURA 11 - CRUZ, Mônica Lachman da. Sem Título, 2019. Díptico, colorida.
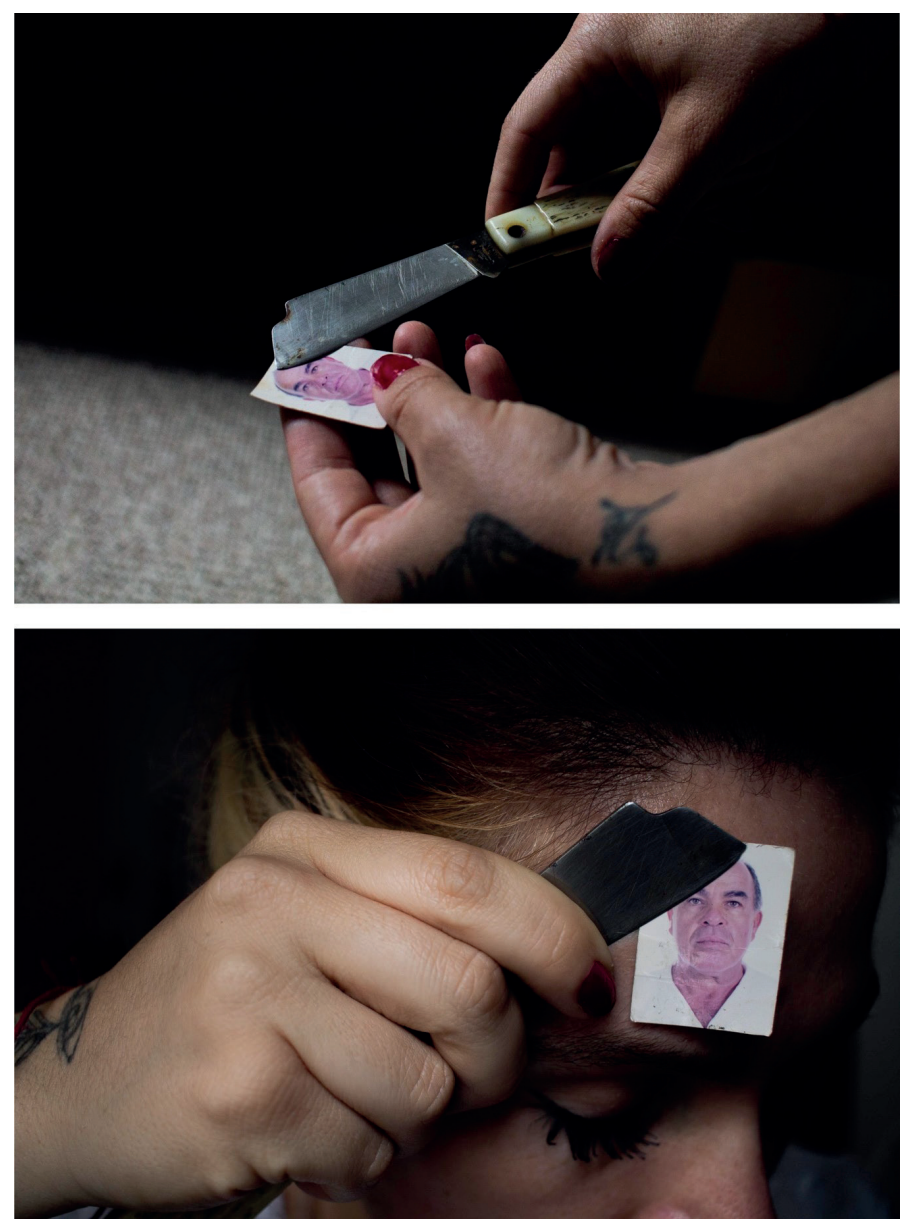

Fonte: Acervo pessoal. 


\section{Poesia do luto através da imagem: uma visita aos campos da memória}

FIGURA 12 - CRUZ, Mônica Lachman da. Sem Título, 2019. Díptico, colorida.

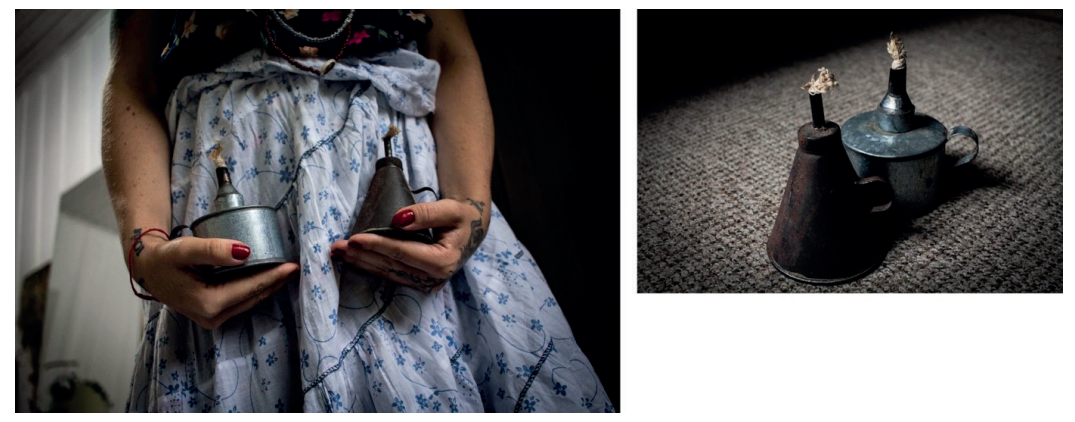

Fonte: Acervo pessoal.

FIGURA 13 - CRUZ, Mônica Lachman da. Sem Título, 2019. Quadríptico, colorida.
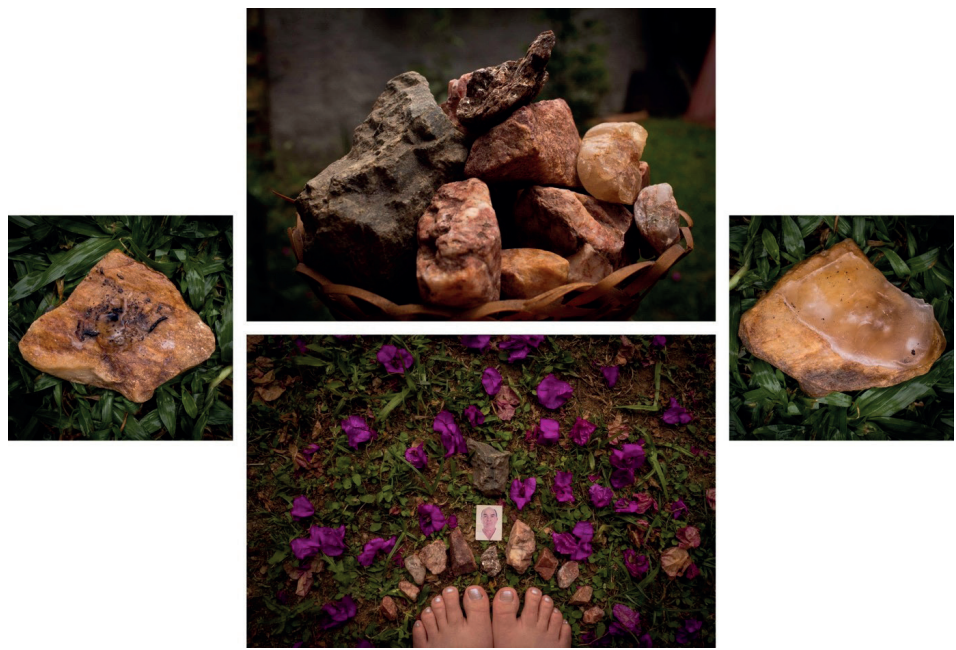

Fonte: Acervo pessoal. 


\section{Poesia do luto através da imagem: uma visita aos campos da memória}

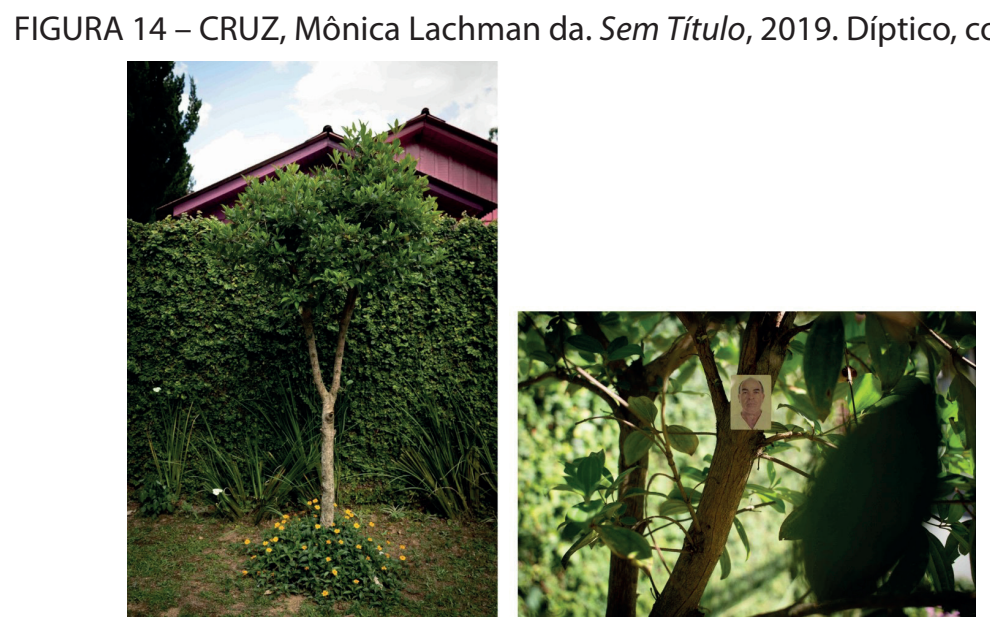

Fonte: Acervo pessoal.

FIGURA 15 - CRUZ, Mônica Lachman da. Sem Título, 2019. Díptico, colorida.
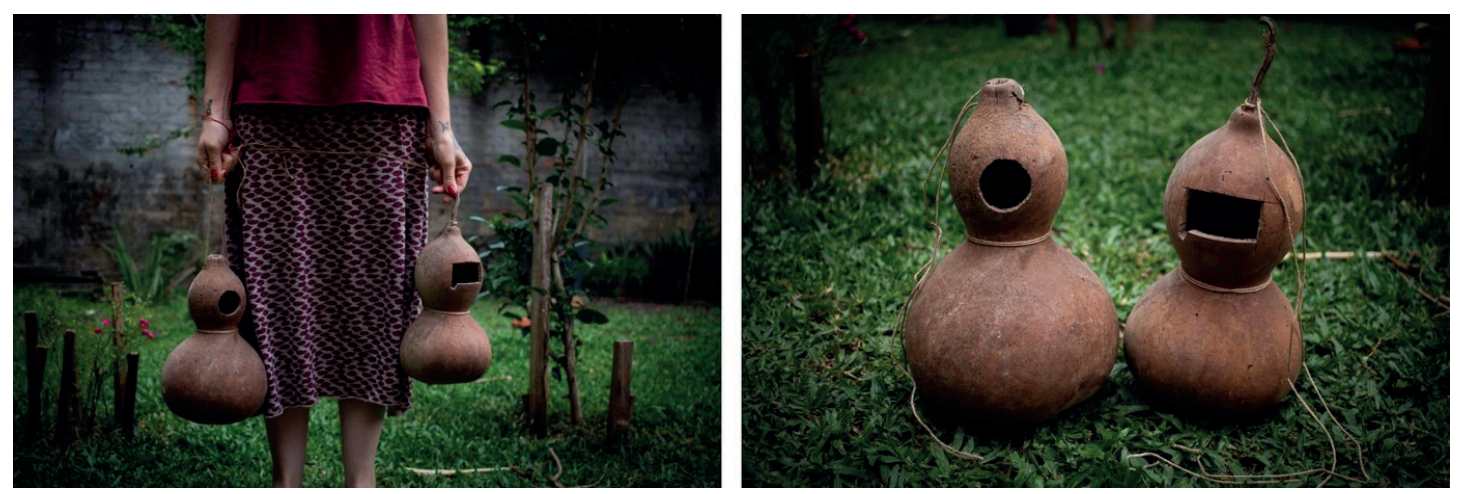

Fonte: Acervo pessoal. 


\section{Poesia do luto através da imagem: uma visita aos campos da memória}

A série aqui apresentada é o resultado de um processo que envolveu meus escritos, leituras, escolhas, dúvidas, reflexões e produções anteriores relacionadas ao assunto da memória. Um processo que reflete desdobramentos e ressignificacões de objetos, lugares, imagens. As fotografias como registro final de obra sugerem observações quanto a poética que as envolvem, por estarem inseridas num outro contexto de relação e espaço, portanto, propondo uma nova linguagem visual.

\section{Considerações finais}

Em quais espaços podem habitar a memória de uma pessoa? Acredito que em todos pelos quais ela passar e deixar seus rastros.

Os objetos de afeto, bem como as fotografias de retrato presentes nesse artigo, não substituem a presença física do meu pai, mas tem a função de rememorar, oferecer a possibilidade de sentimentos, pensamentos acerca da morte e da ressignificação do luto. Eles comportam uma forma de representação desse corpo físico que não está mais ali, com a função de ocupar um determinado espaço afetivo que foi deixado por ele, reconstituindo a presença a partir de "[...] novos suportes repletos de ausências, mas cheios de rastros, traços e vestígios [...]" (SANTOS, 2017, p. 18), profundamente peculiares a essa figura paterna. Quase que igualmente ao olhar os retratos, um novo corpo "se cria" a partir desse contato, uma proximidade sempre se renova com essa figura ausente, o que Barthes chamou de "vínculo umbilical” (BARTHES, 1984, p. 121), “[...] a foto é literalmente a emanação do referente. De um corpo real” (BARTHES, 1984, p. 121).

É sempre um desafio difícil revisitar memórias, ainda mais quando se relacionam a um corpo físico que não está mais presente. Buscar entender o que essas memórias podem nos ensinar, para onde elas nos levam, o que reacendem e questionam em nós através do resgate é para pensarmos. Não é uma prática em vão. Nunca deve ser. 


\section{Poesia do luto através da imagem: uma visita aos campos da memória}

Transformar a dor e a ausência em beleza, buscar a estética dos sentimentos por meio das criações artísticas. Utilizar-se das nossas subjetividades, nossas visões, nossa poética sobre a existência e abraçar a emersão de nossas memórias é dar ao tempo a função de gestar um novo significado para o luto, para a ausência.

A fotografia é, portanto, uma representação da luta contra o esquecimento. A memória é um campo sagrado, guardiã de riquezas, protegê-las é como perpetuá-las e torná-las herança, sem elas permaneceríamos estéreis.

O aprofundamento nas pesquisas relacionadas à morte, luto, memória, fotografia e arte que os autores mencionados no corpo do artigo dialogaram e colaboraram na ampliação da minha visão sobre as diversas veias que levam o pensar sobre cada um desses assuntos, influenciando e enriquecendo na evolução desse trabalho teórico e prático.

\section{Referências}

ARANTES, A. C. A morte é um dia que vale a pena viver. Disponível em: < https://youtu.be/ ep354ZXKBEs>. Acesso em: 18 de out. de 2019.

BARTHES, R. A câmara clara: Nota Sobre a Fotografia. Rio de Janeiro: Nova Fronteira, 1984.

BARTHES, R. Diário de Luto. São Paulo: Martins Fontes, 2011.

CALLE, S. Martine Sonnet. Disponível em < http://www.martinesonnet.fr>. Acesso em: 27 de nov. de 2019.

CUMAN, G. [Des] Ausências: preenchendo lacunas. Universidade Tuiuti do Paraná. Curitiba, 2017. 


\section{Poesia do luto através da imagem: uma visita aos campos da memória}

DIDI-HUBERMAN, G. O rosto e a terra - Onde começa o retrato, onde se ausenta o rosto. Porto Alegre, Porto Alegre, v.9, n.16, p. 61-82, maio, 1998.

ITAPEMA, Thaís. Mascataria onírica. Disponível em <www.facebook.com/mascataria. onirica >. Acesso em: 27 de ago. de 2019.

KANDINSKY, W. Do espiritual na arte - e na pintura em particular. São Paulo: Martins Fontes, 2000.

PAULINO, R. Imagens de sombras. São Paulo : R. Paulino, 2011. 98 p.

REY, S. Por uma abordagem metodológica da pesquisa em artes visuais. In BRITES, Blanca; TESSLER, Elida (Org.) O meio como ponto zero: metodologia da pesquisa em artes plásticas. Porto Alegre: Ed. Universidade/UFRGS, 2002. p.123-140.

SALLES, C. A. Anotações de Daniel Senise: um canteiro de obras. São Paulo, 2003.

SALLES, C. A. Crítica dos Processos Criativos. Florianópolis, 2007.

SANTOS, C. J. dos. Um lugar para o corpo: fotografias familiares em contexto de luto. Rio de Janeiro: Revista M., 2017. p. 8 - 29. 